\title{
SISTEM INFORMASI PENGELOLAAN DATA PENDUDUK DESA PARAKANLIMA SUKABUMI BERBASIS WEB
}

\author{
Wahyu Tisno Atmojo', Erick Dazki², Aditya Bima ${ }^{3}$ \\ ${ }^{1}$ Institut Sains dan Teknologi Pradita \\ ${ }^{2}$ Institut Sains dan Teknologi Pradita \\ ${ }^{3}$ Institut Sains dan Teknologi Pradita
}

Wahyu.tisno@pradita.ac.id, Erick.dazki@pradita.ac.id, Aditya.bima@yahoo.com

\begin{abstract}
Abstrak
Salah satu tugas dari pemerintah desa adalah mengelola data penduduk yang dapat digunakan untuk mengetahui berapa jumlah penduduk dari berbagai tingkatan usia dan juga dari jenis kelamin. Hal tersebut diperlukan untuk mengetahui potensi yang ada dari desa tersebut. Desa Parakanlima adalah sebuah desa yang terletak di kecamatan Cikembar, Kabupaten Sukabumi Jawa Barat dengan jumlah penduduk 7.304 orang. Dalam pelaksanaanya, penyajian data penduduk yang berjalan di desa Parakanlima masih menggunakan papan yang dapat diubah datanya setiap saat dengan menggunakan penghapus, hal tersebut tentu saja sangat tidak efektif dikarenakan setiap saat perubahan data penduduk sangat mungkin terjadi. Oleh karena hal tersebut maka diperlukan sebuah sistem informasi berbasis website yang dapat digunakan untuk mengelola data kependudukan. Tujuan dari pengabdian kepada masyarakat ini adalah membuat sebuah aplikasi berbasis web yang dapat digunakan untuk mengelola data penduduk di desa Parakanlima. Dalam menganalisis dan merancang sistem pengolahan data penduduk akan digunakan metode berorientasi objek Unified Approach (UA) yang terdiri dari tahapan Object Oriented Analysis (OOA) dan Object Oriented Design (OOD) serta menggunakan Unified Modelling Languange (UML) untuk memodelkan kebutuhan sistem. Adapun hasil kegiatan yang telah dilaksanakan adalah dalam bentuk aplikasi pengolahan data penduduk berbasis website yang dapat digunakan oleh pemerintah desa untuk mengelola data-data kependudukan sehingga akan mempermudah dan mempercepat pelayanan kepada masyarakat desa serta terhindar dari duplikasi data.
\end{abstract}

Kata Kunci: Data Penduduk, Sistem Informasi, website, Object Oriented Analysis, Unified Modelling Languange.

\section{PENDAHULUAN}

Dalam revolusi industri 4.0, terdapat istilah internet of things. Dikutip dari website teknojurnal, secara singkat Internet of Things adalah di mana benda-benda di sekitar kita dapat berkomunikasi antara satu sama lain melalui sebuah jaringan seperti internet. (https://teknojurnal.com/definisi-internet-of-things/) Internet merupakan sebuah jaringan komputer yang dapat menghubungkan komputer-komputer diseluruh dunia. Dengan internet maka kita dapat begitu mudahnya mendapatkan informasi kapan saja dan dimana saja. Desa Parakanlima adalah pemerintahan paling bawah dalam struktur pemerintahan di negara Indonesia. Salah satu tugas pemerintah desa adalah melayani warga dalam pembuatan KTP, KK dan lain sebagainya. Dalam pembuatan KTP serta surat-surat yang lain sangat diperlukan data penduduk yang up to date. Permasalahan yang muncul saat ini adalah data penduduk desa parakanlima masih disimpan dalam bentuk excel dan masih disajikan dalam papan Teknologi Informasi dan Komunikasi

155 
sehingga pada saat diperlukan pencarian data penduduk membutuhkan waktu yang lama dan sering terjadinya redudansi (Data ganda) sehingga pada saat diperlukan data-data tersebut kurang update, selain hal tersebut, kadang diperlukan akses jarak jauh untuk mengisi dan mengupdate data warga yang dilakukan oleh sekertaris desa maupun perangkat desa yag lain serta adanya keperluan pemerintah tingkat kecamatan untuk mengakses data warga secara realtime. Saat ini, jika pemerintah kecamatan ingin mengetahui data warga, maka pemerintah kecamatan menghubungi pemerintah desa untuk mengirimkan file excel melalui email. Hal tersebut dirasa kurang efektif dan efisien dan kadang data di excel juga tidak terbaca dikarenakan beda format antara file excel yang digunakan di tingkat desa dengan di tingkat kecamatan. Dari masalah tersebut maka diperlukan sebuah aplikasi berbasis website yang dapat digunakan untuk mengelola data penduduk. Dengan menggunakan aplikasi berbasis website, maka pencarian data akan lebih cepat dan redudansi data tidak akan terjadi serta akses realtime dapat dilakukan oleh pemerintah tingkat desa maupun tingkat kecamatan dapat dilakukan kapan saja dan dimana saja. Oleh karena itu, maka penulis akan membuat sebuah aplikasi berbasis web yang dapat digunakan untuk mengelola data penduduk di desa parakanlima sebagai perwujutan pengabdian masyarakat yang dilakukan penulis. Menurut Abdulloh (2016) Website adalah sejumlah halaman yang menampilkan informasi baik gambar, teks, video maupun audio yang ditampilkan oleh browser. Pengolahan data merupakan sebuah hal yang pasti dilakukan oleh setiap organisasi. Menurut Sutarman (2012), Pengolahan Data adalah proses perhitungan/transformasi data input menjadi informasi yang mudah dimengerti ataupun sesuai dengan yang diinginkan. Dalam perkembanganya, pengolahan data saat ini sudah sewajarnya menggunakan komputer atau yang biasa disebut dengen Electronic Data Processing (EDP). Menurut Jogiyanto (2004) EDP diartikan sebagai merubah data ke dalam bentuk yang lebih bermanfaat yang berupa informasi dengan menggunakan bantuan komputer. Sedangkan menurut Longkutoy (2012) data itu sendiri dapat diartikan sebagai fakta yang berarti kenyataan yang berupa simbol-simbol, huruf maupun angka yang menunjukan suatu objek, ide, gagasan dan lain sebagainya.

Dalam penelitian yang telah dilakukan oleh Didik Setiawan dengan judul Perancangan Sistem Informasi Penduduk Pada Kantor Desa Kebonsari yang dibuat dengan menggunakan Bahasa pemrograman java dengan software netbeans sebagai IDE yang digunakan. Penelitian ini dibuat berdasarkan adanya masalah yang cukup mengganggu pada saat masyarakat akan membuat KTP, KK dan surat-surat lainya. Dalam penelitian ini disimpulkan bahwa dengan adanya aplikasi ini maka akan mengurangi kesalahan yang terjadi pada manajemen pengolahan data penduduk Desa Kebonsari seperti data penduduk ganda.

Dalam penelitian yang telah dilakukan oleh Al Fath Riza Kholdani dengan judul Pembangunan Sistem Informasi Pengolahan Data Penduduk Di Kecamatan Banjarbaru Utara menyatakan bahwa dengan adanya system informasi yang telah dirancang maka dapat membantu untuk menyelesaikan pendataan data desa, data IMB, data izin keramaian, data izin usaha, data pernikahan, data pindah, data tidak mampu, data keadaan tanah, data e-ktp, data domisili dan data kartu keluarga. Sistem yang dibangun menggunakan Bahasa pemrograman php dengan database MySql. Tools bantu untuk merancang system menggunakan pendekatan terstruktur dengan DAD sebagai alat bantunya.

Dalam penelitian yang dilakukan oleh Ani Kusumawati dengan judul Sistem Informasi Kependudukan Pada Kecamatan Kadungora Kabupaten Garut, menyatakan bahwa masalah terbesar saat ini adalah mekanisme pengolahan data penduduk dan data administrasi kependudukan yang dilakukan sering mengalami kesulitan yang disebabkan oleh pengolahan data yang dilakukan tidak terpusatsehingga menyebabkan kendala pada saat pelaporan dan monitoring yang mengakibtakan pengambilan keputusan yang tidak tepat. Berdasarkan masalah tersebut, maka dibuatlah sebuah sistem pengelolaan data kependudukan berbasis web yang dapat menyelesaikan masalah yang ada. Dalam penelitian ini digunakan metode waterfall dengan Bahasa pemrograman PHP dan menggunakan pendekatan Object Oriented Programing dalam merancang sistemnya.

Teknologi Informasi dan Komunikasi 156 


\section{METODE}

Dalam melakukan pengabdian masyarakat dan menyusunyanya menjadi penelitian, penulis menggunakan beberapa Teknik pengumpulan data antara lain 1) observasi dengan cara melakukan pengamatan langsung terhadap proses pendataan penduduk di desa Parakanlima. 2) Metode wawancara, dengan cara melakukan tanya jawab secara langsung dengan perangkat desa dan warga mengenai prosedur pendataan warga. 3) Studi pustaka, penulis membaca berbagai sumber referensi baik buku maupun jurnal untuk mendukung penelitian ini.

Sedangkan untuk membuat system informasi berbasis web, maka penulis menggunakan metode berorientasi objek Unified Approach (UA) yang terdiri dari tahapan Object Oriented Analysis (OOA) dan Object Oriented Design (OOD) serta menggunakan Unified Modelling Languange (UML) untuk memodelkan kebutuhan sistem. Menurut Ali Bahrami (1999) tahapan metode Unified Approach adalah 1) Tahap analisis dimana penulis melakukan analisis dengan cara mengidentifikasi actor, pengembangan diagram usecase dan diagram aktifitasdan mengidentifikasi kelas-kelas, relasi, atribut dan method. Sedangkan tahap ke 2 adalah tahap perancangan dimana penulis melakukan perancangan user interface dan melakukan pengujian. Bahasa pemrograman yang digunakan adalah PHP dan database MySql. Menurut Kadir (2013) PHP atau PHP Hypertex Preprocessor adalah sebah bahasa pemrograman yang ditujukan untuk pembuatan aplikasi website yang dinamis. Sedangkan menurut Mysql menurut Arief (2011) menyatakan bahwa Mysql Adalah jenis databse server yang sering digunakan untuk membuat aplikasi berbasis website sebagai sumber pengolahan dan penyimpanan datanya.

\section{HASIL DAN PEMBAHASAN}

\section{Perancangan sistem}

Dalam metode Unified Approach (UA) yang pertama adalah tahapan Object Oriented Analysis. Dalam tahapan ini akan dirancang seperti apa system yang nantinya akan berjalan dengan menggunakan diagram use case dan diagram activity. Adapun diagram use case yang akan diusulakn terlihat dari gambar 1 dibawah ini.

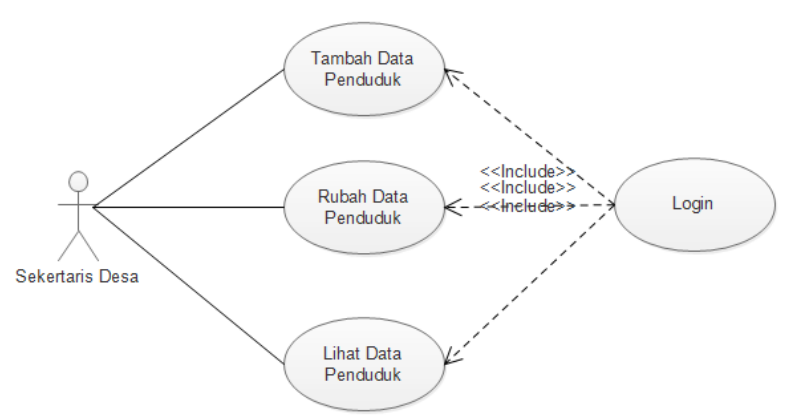

Gambar 1 Use Case Diagram sistem usulan

Setelah usecase diagram dibuat, maka akan dibuat masing-masing usecase tersebut kedalam activity diagram. Adapun activity diagram menu login terlihat dari gambar 2 dibawah ini.

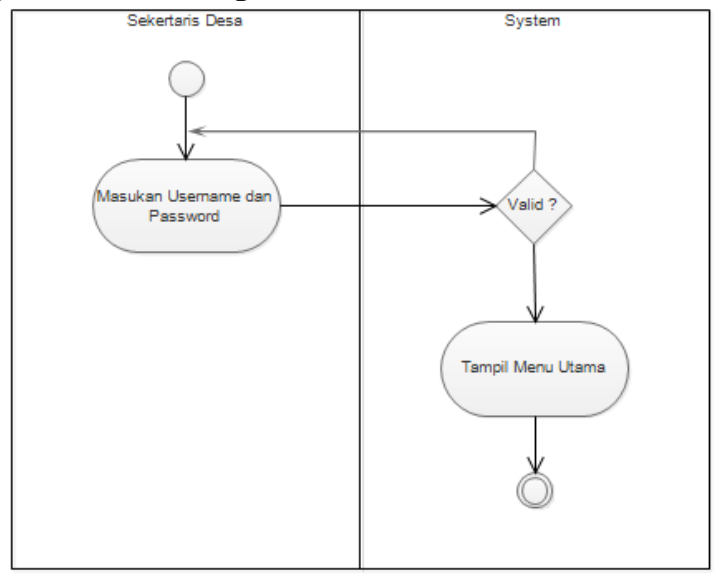

Gambar 2 Activity diagram menu Login

Activity diagram menu tambah data penduduk terlihat dari gambar 3 dibawah ini.

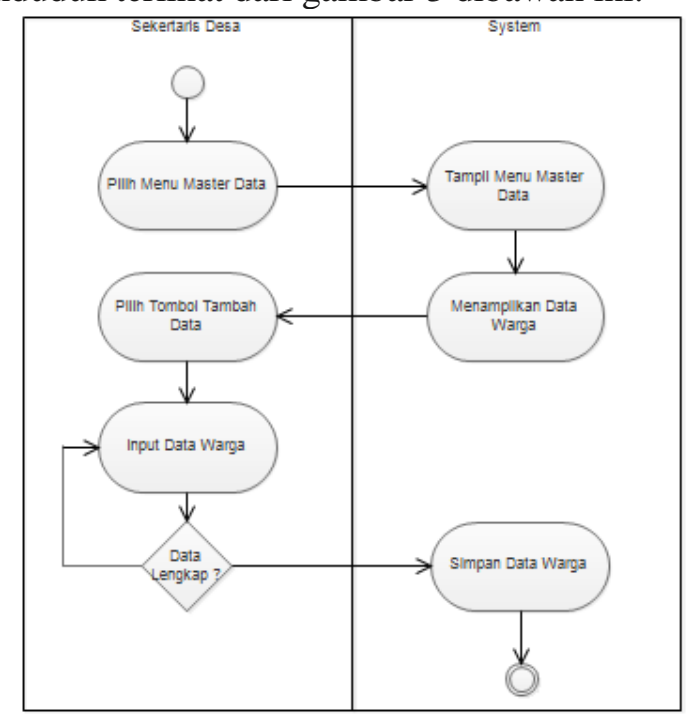

Gambar 3 Activity Diagram Menu Tambah Data Warga

Teknologi Informasi dan Komunikasi 
Activity diagram menu rubah data penduduk terlihat dari gambar 4 dibawah ini.

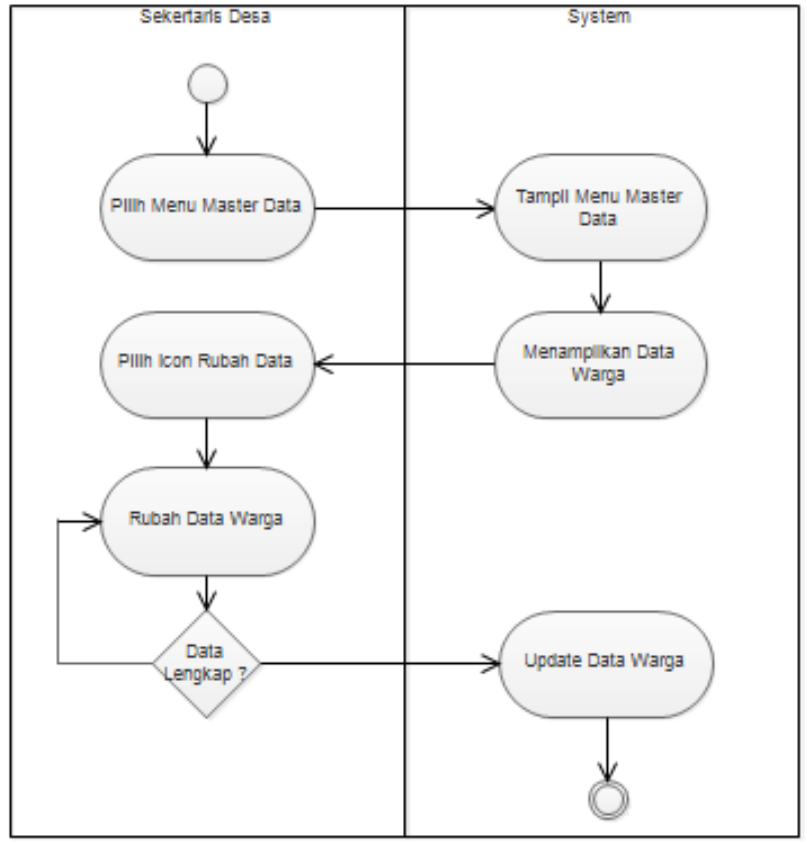

Gambar 3 Activity Diagram Menu Rubah Data Warga

Activity diagram menu lihat data penduduk terlihat dari gambar 4 dibawah ini.

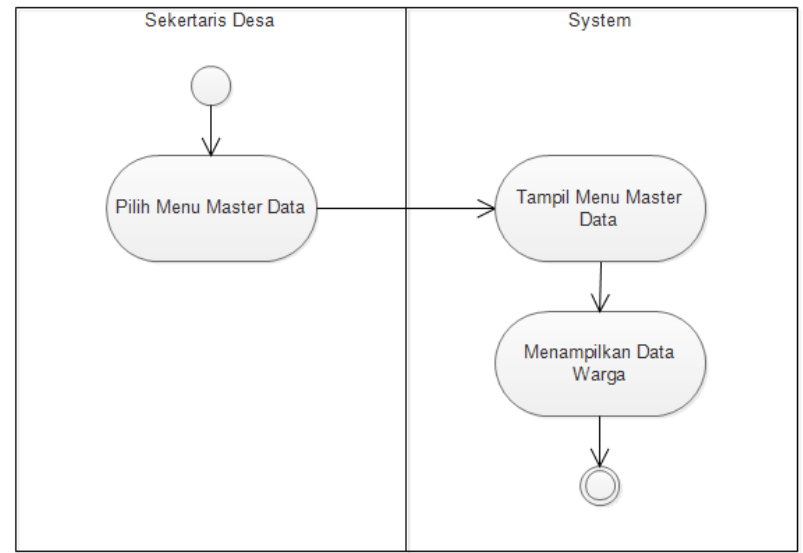

Gambar 4 Activity Diagram Menu Tampil Data Warga

Setelah dibuat activity diagram, maka selanjutnya akan dibuat class diagram untuk memetakan kebutuhan database. Activity diagram terlihat dalam gambar 5 dibawah ini.

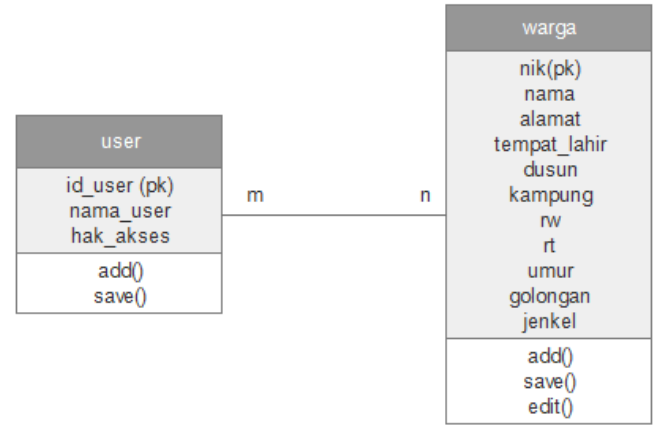

Gambar 5 Class Diagram

\section{Implementasi sistem}

Setelah tahapan analisis dilakukan, maka selanjutnya dilakukan tahap perancangan. Dalam tahapan ini dilakukan perancangan layer dan dilanjutkan dengan implementasi. Dalam system informasi pengolahan data warga in terdiri dari 3 menu yaitu menu login yang digunakan untuk masuk ke sistem. Setalah berhasil login, maka selanjutnya akan muncul menu utama dimana di menu utama terdapat menu master data. Dalam menu master data, admin dapat melakukan fungsi CRUD (Create, Read, Update dan Delete) data warga. Setelah dilakukan perancangan user interface, maka tahap selanjutnya adalah implementasi dari rancangan user interface tersebut. Adapun implementasi dari menu login dapat dilihat di gambar 6 dibawah ini.

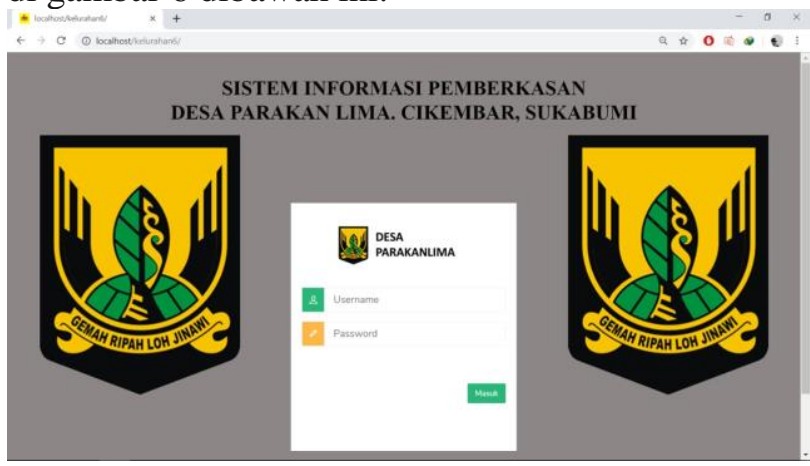

Gambar 6 Menu Login

Setelah berhasil login maka masuk ke menu utama, adapun tampilan menu utama terlihat di gambar 7 dibawah ini. 


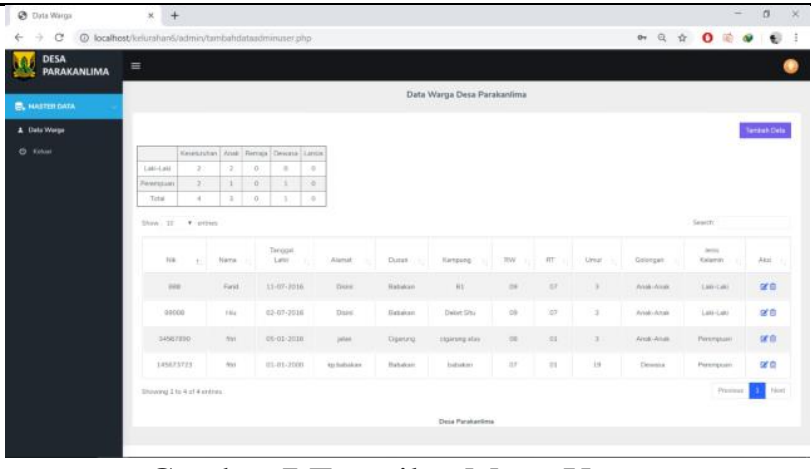

Gambar 7 Tampilan Menu Utama

Dalam menu data warga, user dapat melakukan penambahan data warga. Adapun tampilan menu penambahan data warga terlihat dalam gambar 8 dibawah ini.

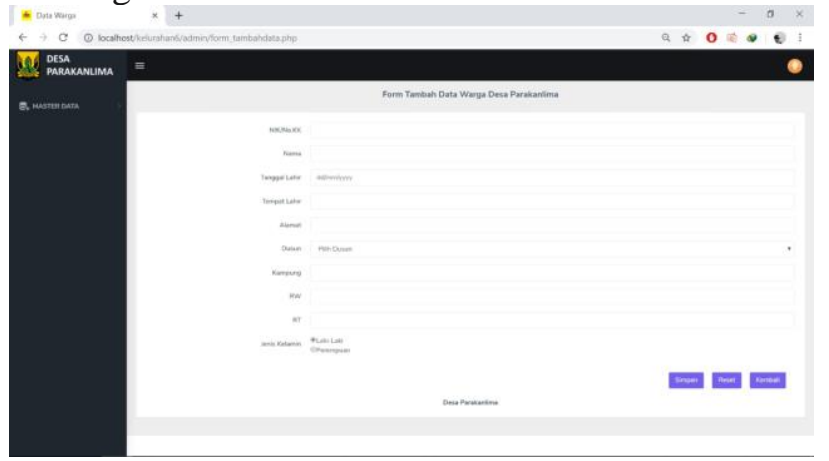

Gambar 8 Tampilan Menu Tambah Data Warga

Selain melakukan tambah warga, user juga dapat melakukan perubahan data warga, adapun tampilan dari menu rubah data warga terlihat dalam gambar 9 dibawah ini:

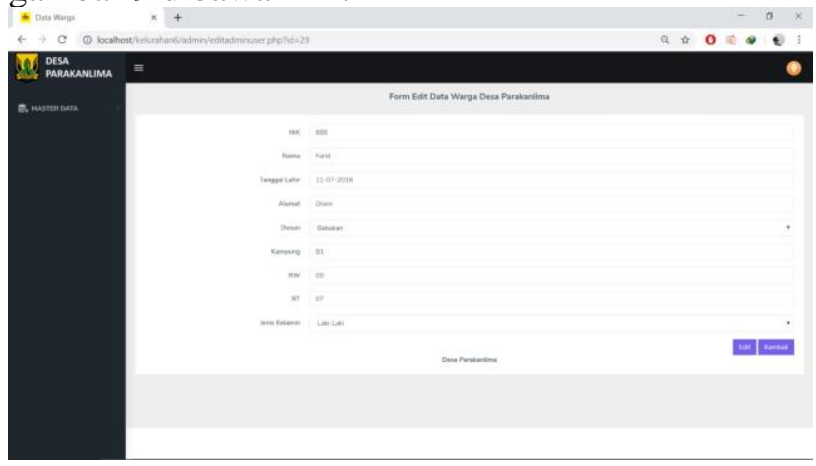

Gambar 9 Tampilan Menu Rubah Data Warga

\section{Pengujian Sistem}

Setelah diimplementasikan, tahapan selanjutnya adalah melakukan pengujian system. Sistem diuji dengan menggunakan metode blckbox testing. Adapun hasil pengujian terlihat dalam table 1 dibawah ini.
Tabel 1 Hasil Pengujian Black Box Testing

\begin{tabular}{|c|c|c|c|c|}
\hline No & Menu & Skenario Pengujian & Hasil Yang diharapkan & Hasil Pengujian \\
\hline \multirow[t]{3}{*}{1} & Menu Login & Username atau passwordkosong & $\begin{array}{l}\text { Sistem akan menolak } \\
\text { dan memberi pesan } \\
\text { error "Username atau } \\
\text { passwordkosong" }\end{array}$ & Valid \\
\hline & & Username atau password salah & $\begin{array}{l}\text { Si stem akan menolak } \\
\text { dan memberi pesan } \\
\text { error "Username atau } \\
\text { password salah" }\end{array}$ & Valid \\
\hline & & Username dan password benar & $\begin{array}{l}\text { Sistem akan } \\
\text { menampilkan menu } \\
\text { utama }\end{array}$ & Valid \\
\hline \multirow[t]{2}{*}{2} & $\begin{array}{l}\text { Menu } \\
\text { Tambah Data } \\
\text { Warga }\end{array}$ & Salah satu data tidak diisi & $\begin{array}{l}\text { Si stem akan } \\
\text { memberikan pesan } \\
\text { "Data ti dak lengkap, } \\
\text { silakan lengkapi data } \\
\text { warga!" }\end{array}$ & Valid \\
\hline & & Semuadata diis & $\begin{array}{l}\text { Sistem akan } \\
\text { menampilkanpesan } \\
\text { "Databerhasil } \\
\text { di simpan" }\end{array}$ & Valid \\
\hline \multirow[t]{2}{*}{3} & $\begin{array}{l}\text { Menu Rubah } \\
\text { DataWarga }\end{array}$ & Salah satu data tidak diisi & $\begin{array}{l}\text { Si stem akan } \\
\text { memberikan pesan } \\
\text { "Data ti dak lengkap, } \\
\text { silakan lengkapi data } \\
\text { warga!" }\end{array}$ & Valid \\
\hline & & Semuadata diis & $\begin{array}{l}\text { Sistem akan } \\
\text { menampilkanpesan } \\
\text { "Data berhasil } \\
\text { diupdate" }\end{array}$ & Valid \\
\hline
\end{tabular}

Untuk mengetahui apakah system diterima atau tidak, maka dilakukan pengujian beta dengan menyebarkan kuisioner kepada 5 orang petugas kelurahan dengan pertanyaan dan jawaban terlihat di table 2 dibawah ini.

Tabel 2 Pertanyaan dan Jawaban Responden

\begin{tabular}{|c|l|c|c|c|c|c|}
\hline Pernyataan No & \multicolumn{1}{|c|}{ Pernyataan Quisioner } & $\mathbf{1}$ & $\mathbf{2}$ & $\mathbf{3}$ & $\mathbf{4}$ & $\mathbf{5}$ \\
\hline 1 & Aplikasi ini bermanfaat & 0 & 0 & 0 & 0 & 5 \\
\hline 2 & Tampilan aplikasi ini menarik & 0 & 0 & 0 & 2 & 3 \\
\hline 3 & Aplikasi ini mudah dioperasikan & 0 & 0 & 0 & 3 & 2 \\
\hline 4 & Aplikasi ini mempunyai fungsi yang diharapkan & 0 & 0 & 0 & 0 & 5 \\
\hline 5 & Fitur-fitur aplikasi yang ada sudah memuaskan & 0 & 0 & 0 & 3 & 2 \\
\hline 6 & Aplikasi ini layal di aplikasikan di kelurahan & 0 & 0 & 2 & 0 & 5 \\
\hline
\end{tabular}

Setelah dilakukan pengolahan data terhadap hasil kuisioner, maka didapatkan data bahwa responden sangat setuju bahwa aplikasi ini dapat digunakan sebesar $73 \%$ dan sebanyak $27 \%$ sisanya menyatakan setuju aplikasi ini dapat digunakan. Untuk mengetahui hasil pengolahan data kuisioner dapat terlihat dari gambar 9 dibawah ini.

\section{Kesimpulan Hasil Kuisioner Pengujian}

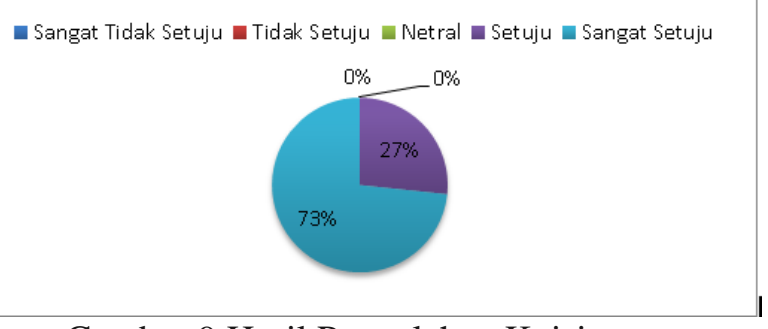

Gambar 9 Hasil Pengolahan Kuisioner

Teknologi Informasi dan Komunikasi 


\section{KESIMPULAN}

Setalah dilakukan pengabdian masyarakat di desa Parakanlima dan dibuat dalam bentuk penelitian, maka dapat disimpukan hal-hal sebagai berikut: 1) Aplikasi ini sangat membantu petugas kelurahan dalam mengelola data warga, hal tersebut tercermin dari hasil kuisioner yang telah disebar oleh penulis dimana sebanyak $73 \%$ petugas kelurahan sangat setuju jika aplikasi ini dapat diterapkan sedangkan sebanyak $27 \%$ setuju untuk menerapkan aplikasi ini. 2) Dengan dibuatnya sistem informasi pengolahan data warga berbasiss web ini, maka sekertaris desa maupun petugas kelurahan yang lain dapat melakukan update data dari berbagai tempat tanpa harus hadir di kelurahan.

\section{SARAN}

Untuk pengembangan aplikasi selanjutnya, penulis menyarankan beberapa hal sebagai berikut : 1) Aplikasi ini masih hanya sebatas pengolahan data warga yang berguna untuk mengklasifikasikan data warga berdasarkan jenis kelamin dan usia, untuk penelitian selanjutnya disarankan untuk mengembangkan aplikasi ini menjadi aplikasi yang komplek dengan menambahkan fitur pembuatan kartu keluarga dan surat-surat yang diperlukan oleh warga. 2) Aplikasi ini hanya sebatas digunakan oleh sekertaris desa dan petugas kelurahan untuk melakukan update data warga, simpan data warga dan menambah data warga. Kedepanya diharapkan aplikasi dapat diakses juga oleh masyarakat umum untuk mengetahui data-data warga di kelurahan tersebut.

\section{REFERENSI}

Abdulloh, Rohi (2016). Easy and Simple Web Programing. Jakarta : Elex Media Komputindo.

Al Fath Riza Kholdani. Jurnal Technologia Vol 8 No 3 Juli 2017, Pages: 135-145. Pembangunan Sistem Informasi Pengolahan
Data Penduduk di Kecamatan Banjarbaru Utara. (https://ojs.uniskabjm.ac.id/index.php/JIT/article/download/1 117/940). Diakses pada tanggal 13 Agustus 2019

Ani Kusumawati, Tacbir Hendro Pudjiantoro, Dian Nursantika. Prosiding Seminar Nasional Komputer dan Informatika (Senaski) 2017, pages 27-34, No Isbn: 978-602-6050-1-2. Sistem Informasi Kependudukan Pada Kecamatan Kadungoro Kabupaten Garut. https://ojs.unikom.ac.id/index.php/senaski/a rticle/view/893/675 diakses pada 15 Agustus 2019.

Arief, M. Rudianto (2011) Pemrograman Web Dinamis Menggunakan Php dan Mysql. Yogyakarta : Andi

Didik Setiawan, Yhoni Agus Setya Mahendra, IJNS, Indonesian Journal on Networking and Security Volume 4 No 2 April 2015. No Issn : 2302-5700. Perancangan Sistem Informasi Penduduk Pada Kantor Desa Kebonsari https://ijns.org/journal/index.php/ijns/article ldownload/1309/1297 diakses pada 15 Agustus 2019.

Ramadhoni, Faisal. (2014) Pengertian internet of Things, diambil dari https://teknojurnal.com/definisi-internet-ofthings/ diakses pada tanggal 16 Agustus 2019.

Jogiyanto. H.M (2004) Analisis dan Desain Sistem Informasi. Yogyakarta : Andi

Kadir, Abdul (2013) Buku Pintar Programer Pemula PHP. Yogyakarta : Mediakom

Longkutoy. J. John (2012). Pengenalan Komputer. Yogyakarta : Andi

Sutarman. 2012. Pengantar Teknologi Informasi. Jakarta: PT. Bumi Aksara. 